
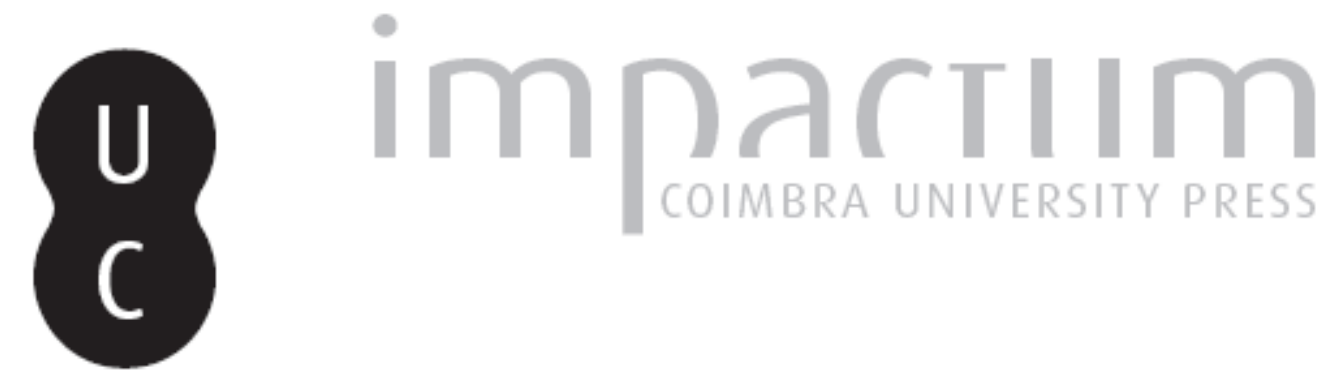

\title{
A revolução nacional de 1926: da ditadura militar à formação do Estado Novo
}

Autor(es): $\quad$ Cruz, Manuel Braga da

Publicado por: Imprensa da Universidade de Coimbra

URL persistente:

URI:http://hdl.handle.net/10316.2/45079

DOI:

DOI:https://doi.org/10.14195/2183-8925_7-2_10

Accessed : $\quad$ 26-Apr-2023 04:59:50

A navegação consulta e descarregamento dos títulos inseridos nas Bibliotecas Digitais UC Digitalis, UC Pombalina e UC Impactum, pressupõem a aceitação plena e sem reservas dos Termos e Condições de Uso destas Bibliotecas Digitais, disponíveis em https://digitalis.uc.pt/pt-pt/termos.

Conforme exposto nos referidos Termos e Condições de Uso, o descarregamento de títulos de acesso restrito requer uma licença válida de autorização devendo o utilizador aceder ao(s) documento(s) a partir de um endereço de IP da instituição detentora da supramencionada licença.

Ao utilizador é apenas permitido o descarregamento para uso pessoal, pelo que o emprego do(s) título(s) descarregado(s) para outro fim, designadamente comercial, carece de autorização do respetivo autor ou editor da obra.

Na medida em que todas as obras da UC Digitalis se encontram protegidas pelo Código do Direito de Autor e Direitos Conexos e demais legislação aplicável, toda a cópia, parcial ou total, deste documento, nos casos em que é legalmente admitida, deverá conter ou fazer-se acompanhar por este aviso.

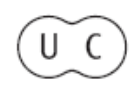




\section{REVISTA DE HISTORIA DAS IDEIAS 7}

\section{REVOLTAS E REVOLUCOẼS}

\section{**}

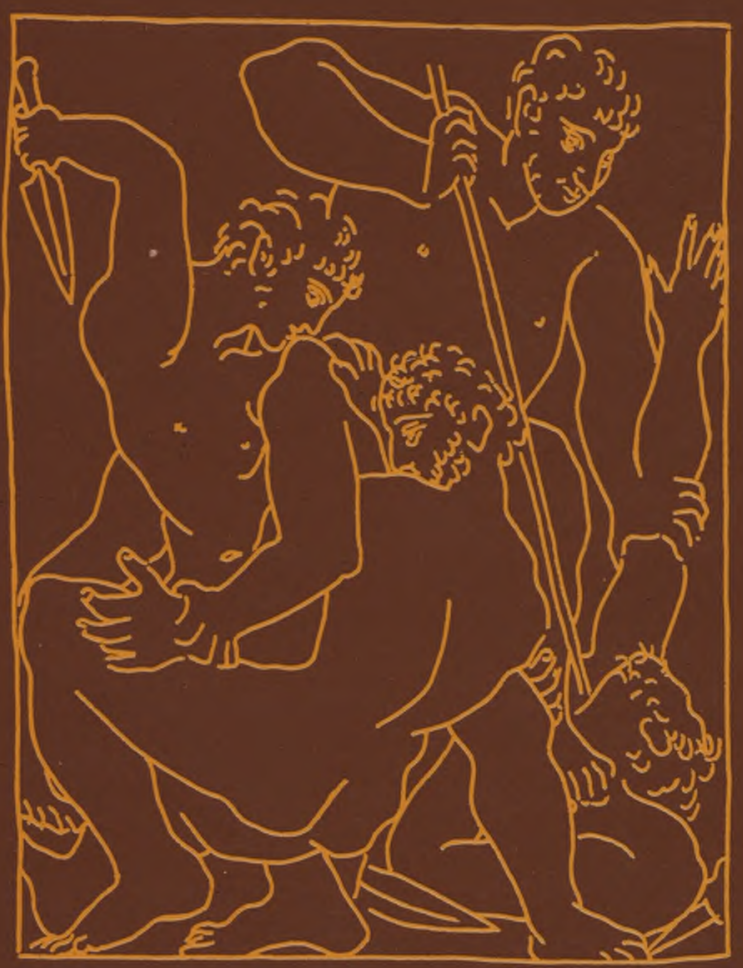

INSTITUTO DE HISTÓRIA E TEORIA DAS IDEIAS FACULDADE DE LETRAS 


\section{A REVOLUÇÃO NACIONAL DE 1926: DA DITADURA MILITAR À FORMAÇÃO DO ESTADO NOVO}

O levantamento militar de 28 de Maio de 1926 fez-se mais contra um estado de coisas, com uma intenção sobretudo negativa, do que pela instauração de um programa previamente concebido. A insurreição não foi feita por um partido ou movimento político, com propósitos ideológicos forjados na luta do parlamentarismo democrático, mas antes pelas Forças Armadas, sem ideário preciso, caldeando no seu interior intenções ambíguas e projectos contraditórios. Unia-as apenas o protesto contra a partidocracia, a ineficácia parlamentar, a instabilidade governativa, o descrédito das instituições e a agitação social.

Não admira pois que, logo nos primeiros dias, perante a indefinição de objectivos claros do movimento militar, se tenha assistido ao despoletar de dissenções internas entre os revoltosos, à confrontação de propósitos e atitudes, bem como à tentativa de apropriação e controle políticos do movimento, ou de instrumentalização da sua vitória para diferentes desígnios políticos.

O que começou por ser um levantamento militar, depressa se tornou revolução, dando origem a uma ditadura militar, e redundando anos depois em novo regime político. A formação do Estado Novo, através desta sucessão histórica, resulta dos compromissos encontrados como resposta aos vários conflitos que se foram produzindo ao longo desta transição.

O primeiro conflito pode dizer-se que surgiu em torno da alternativa «reforma ou revolução» que logo de início se pôs, traduzida pelo dilema «continuidade ou ruptura» do sistema, da constituição, do regime até, e personificada nos dois ${ }^{(*)}$

(*) Instituto de Ciências Sociais da Universidade de Lisboa. 


\section{Revoltas e Revoluções}

movimentos militares que simultaneamente eclodiram e nas figuras dos respectivos chefes: o que se forjou em Lisboa, em torno da Junta Revolucionária liderada pelo Comandante Mendes Cabeçadas, partidário da primeira alternativa; e o que partiu de Braga comandado pelo General Gomes da Costa, inclinado para a segunda hipótese. É o conflito cuja resolução ocupa a primeira fase da transição, e que termina a 17 de Junho com o afastamento de Cabeçadas por Gomes da Costa, com a ruptura constitucional e a instauração da Ditadura Militar.

$\mathrm{O}$ segundo conflito produz-se, posteriormente à resolução do primeiro, à volta da questão do regime, isto é, com base na confrontação dos propósitos dos que pensaram aproveitar e encaminhar a revolução no sentido da restauração dé uma monarquia integral, e dos que se limitavam a realizar a revolução política no quadro das instituições republicanas, mas numa perspectiva nacionalista. É um drama em vários actos, que começa com a deposição de Gomes da Costa a 9 de Julho de 1926 e se encerra (embora nunca definitivamente) com o frustrado «golpe dos fifis» a 12 de Agosto de 1927. Constitui uma segunda fase da transição para o Estado Novo, e resolve-se pela manutenção do regime e das instituições republicanas, de que a eleição de Carmona a 25 de Março de 1928 é a primeira garantia.

O terceiro conflito dá-se em torno da questão religiosa. Começa com a publicação do decreto sobre a «personalidade jurídica» da Igreja, conhece um momento particularmente significativo com a entrada definitiva de Salazar para o Ministério das Finanças, e resolve-se pelo compromisso que se segue à crise da «portaria dos sinos» nos começos de Julho de 1929. A questão confessional do poder ficou desse modo implicitamente resolvida, consagrando-se desde logo o regime de separação futuramente concordatado.

Um último conflito, porventura mais decisivo, desenrola-se em torno do sistema partidário a consagrar constitucionalmente, e que se vai resolvendo desde o anúncio de lançamento da União Nacional a 30 de Julho de 1930 até à «plebiscitação» do texto constitucional a 19 de Março de 1933, embora ainda com importantes epílogos posteriores, e que passa pela fixação de estatuto à oposição.

Estes dois últimos conflitos, embora não perfazendo fases rigorosas temporais da transição, até porque não permanecerão definitivamente fechados, sucedem-se no tempo com relativa progressão cronológica, e por isso assim os enumeramos por esta ordem.

A formação do Estado Novo que se processa ao longo destes anos, é a resultante destes principais enfrentamentos de 
tendências, que relegaram alguns dos insurrectos de 28 de Maio de 1926 para as fileiras da oposição, e cooptaram por outro lado antigos primo-republicanos, realizando consensos que se consubstanciarão na plataforma compromissória da Constituição de 1933.

\section{Um movimento revolucionário...}

Para muitos dos militares que aderiram ao movimento, o que estava em causa era apenas o saneamento do sistema político constitucional republicano, a sua reforma e nunca a sua supressão e substituição. Assim se explica que quase todos os partidos adversários do Partido Democrático, desde a União Liberal Republicana de Cunha Leal à Esquerda Democrática de José Domingos dos Santos, passando por radicais e nacionalistas, se tenham regozijado com o levantamento, e muitos tenham até reivindicado a paternidade do golpe. Mas para outros militares, porém, o que importava era alterar o próprio sistema de representação partidária até então em vigor, senão mesmo o regime.

São claro indício deste contraste de intenções os propósitos enunciados nas primeiras proclamações políticas dos Revoltosos. Assim, o Manifesto da Junta de Salvação Pública, liderada por Cabeçadas e Gama Ochoa, posto a circular em Lisboa na madrugada do dia 29 de Maio, anunciava, como primeira medida fundamental e urgente, a «publicação do Estatuto fundamental que, mantendo essencialmente o regime republicano proclamado em 1910 e reconhecido pelas potências, introduza as modificações necessárias para garantir o seu regular funcionamento», a par de uma série de outras medidas reformistas de governação de ordem administrativa, financeira, económica, educacional, judicial, colonial e militar, terminando porém por afirmar também a "garantia insofismável dos direitos de vida, propriedade e bom nome do cidadão» 0 ).

Eram outras porém as intenções manifestadas pelas proclamações de Gomes da Costa, emanadas de Braga no próprio dia 28: «Para homem de dignidade e honra, a situação política do País é inadmissível. Vergada sob a acção de uma minoria devassada e tirânica, a Nação, envergonhada, sente-se morrer», dizia a primeira. E a segunda precisava: «A Nação quer um Governo Nacional militar, rodeado das melhores competências, para instituir na administração do Estado a disciplina e a hon-

0) In João Ameal (dir.), Anais da Revolução Nacional, Barcelos, Comp. Editora do Minho, vol. I, p-p. 26-27. 
radez que há muito perdeu.... Não quer a Nação uma Ditadura de políticos irresponsáveis, como tem sido até agora. Quer um governo forte, que tenha por missão salvar a Pátria, que concentre em si todos os poderes para, na hora própria, os retribuir a uma verdadeira representação nacional, ciosa de todas as liberdades, representação que não será de quadrilhas políticas, mas de interesses mais vivos e permanentes de Portugal. Entre todos os corpos da Nação em ruína é o Exército o único com autoridade moral e força material para consubstanciar em si a unidade de uma Pátria que não quer morrer. À frente do Exército Português, pois, unido na mesma aspiração de redenção patriótica, proclamo o Interesse Nacional contra a acção nefasta dos políticos, e ofereço à Pátria enferma um governo forte, capaz de opor aos inimigos internos o mesmo heroico combate que o Exército deve aos inimigos externos» $\left({ }^{2}\right)$.

Enquanto Cabeçadas procurava assegurar a continuidade e a legitimidade constitucional, Gomes da Costa exigia a ruptura com a legalidade constitucional. Enquanto Cabeçadas dizia a um repórter do Século logo no dia 29 que o movimento não era radical, nem contra nem a favor de nenhum partido, mas que apenas pretendia «libertar este desgraçado País do predomínio de um partido que o tem levado à sua miserável situação de hoje, não hesitando em servir-se de todos os meios de corrupção, transformando-o num feudo em que se afogam todas as nossas tradições»» $\left({ }^{3}\right)$, Gomes da Costa, pelo contrário, confidenciava ao jornalista Norberto Lopes que o seu objectivo é «levar o Exército a intervir na política», «constituir um governo militar composto pelas pessoas que dirigiram o Movimento, para que as suas intenções não sejam atraiçoadas», formar um triunvirato «rodeado dum Conselho Técnico», dissolver o parlamento e demitir o Presidente da República $\left(^{4}\right)$.

As estratégias seguidas pelas duas expressões do movimento denunciam esse mesmo dualismo de propósitos fundamentais.

Logo no dia 28, Cabeçadas escreveu ao Presidente da República Bernardino Machado uma carta em que, em nome da «grande maioria do Exército», lhe pedia que nomeasse «um governo de carácter extra-partidário constituído por republicanos que mereçam a confiança do País» $\left(^{5}\right)$.

De facto, perante o avanço imparável do movimento, quer pelo apoio que lhe é expresso pela opinião pública, quer pelas

O Idem, pp. 22-23.

(3) Idem, p. 32.

C) Idem, pp. 32-33.

C) Idem, p. 27. 
adesões militares que desencadeia, a que se junta na tarde de 29 de Maio a das guarnições de Lisboa, o Governo, para facilitar os movimentos a Bernardino Machado, apresentou a sua demissão. O Presidente, por sua vez, consciente das facções que se esboçavam no movimento, convidou então Mendes Cabeçadas a formar um «governo nacional», a 30 de Maio, num claro intuito de, ao privilegiar Cabeçadas, secundarizar Gomes da Costa, e numa nítida tentativa de, através do compromisso, salvar a continuidade constitucional do regime.

Empossado a 30 de Maio, Cabeçadas concentra na sua pessoa, interinamente, todas as pastas do Ministério, enquanto acorda com Bernardino Machado que pediria às Câmaras poderes excepcionais. Perante a inevitabilidade de uma Ditadura, Bernardino Machado procura a todo o transe evitar que ela seja militar, primeiro, e que seja apesar disso «ditadura constitucional», depois.

Gomes da Costa, que não fora ouvido, sente que em Lisboa se procuram ludibriar pelo controlo os ideais que proclamara para a Revolução. Em declarações proferidas no Porto exige por isso a formação de uma direcção militar do governo, contra a constituição de um governo de políticos.

«Sei que vários elementos políticos procuram instantemente empalmar o Movimento e desvirtuar o pensamento que presidiu à sua organização. Eu detesto os políticos e nunca os consentirei junto de mim. Em Lisboa, está já organizado um governo. Alguém que estava comigo deixou-se empolgar... Não o consentiremos!» $\left.{ }^{6}\right)$. Decide por isso marchar com as suas tropas para o Sul e apertar o cerco a Lisboa para forçar Cabeçadas aos seus propósitos.

A resposta de Gomes da Costa às manobras palacianas de Lisboa produz os seus efeitos. A 31 de Maio são encerradas as Câmaras e Bernardino Machado vê-se forçado a apresentar a sua demissão. Considerando que a sua missão está esgotada, entrega o poder nas mãos de Cabeçadas, dizendo-lhe em carta que, «em conformidade com a Constituição, o Ministério em conjunto assumirá a plenitude do poder executivo» ( ${ }^{7}$ ). Era o último mas hábil expediente do Presidente cessante para preservar a legitimidade republicana. E Cabeçadas desloca-se a Coimbra para conciliar actuações com Gomes da Costa.

Do encontro de Coimbra entre os dois chefes das duas alas do Movimento, a 1 de Junho, sai a resolução da formação

(6) Idem, p. 48.

(7) Idem, p. 54. 


\section{Revoltas e Revoluções}

de um triunvirato militar, que distribuirá as pastas entre si, composto por Gomes da Costa, Cabeçadas e o Comandante Gama Ochoa. Cabeçadas, de regresso a Lisboa, manda publicar, na qualidade de Presidente do Ministério, o decreto de nomeação do novo Governo. Gomes da Costa e o Exército estavam em minoria nesse governo. Além disso, a questão para Gomes da Costa não era de distribuição de pastas, mas de orientação do movimento. Insatisfeito com os resultados concretos do acordo de Coimbra, Gomes da Costa resolve marchar sobre Lisboa para impor definitivamente os seus pontos de vista. No dia 3 chega com as tropas do Norte e do Alentejo a Sacavém, às portas de Lisboa, obrigando Cabeçadas a novo encontro. Novo acordo é feito então em Sacavém, que consiste na designação de uma junta governativa, composta agora por Cabeçadas, por um lado, e por Gomes da Costa e Carmona, por outro, e na formação de um novo governo, onde além de Cabeçadas (Presidência e Interior), Gomes da Costa (Guerra e Colónias), Carmona (Estrangeiros) e Jaime Afreixo (Marinha), apareciam quatro civis: Salazar nas Finanças, Mendes dos Remédios na Instrução, Almeida Ribeiro na Justiça e Ezequiel de Campos na Agricultura e Comércio. Nesse mesmo dia 3 é publicado o decreto de nomeação do Governo, aparecendo porém Manuel Rodrigues no lugar de Almeida Ribeiro.

A consagração desse acordo é feita porém solenemente com a parada militar da vitória. No dia 6 desfilam por Lisboa as tropas que participaram no levantamento, assistindo em tribuna de honra não só a nova Junta Governativa como o próprio corpo diplomático, numa atitude de reconhecimento externo da nova situação.

No dia seguinte iniciava-se a actividade governativa com a posse de alguns ministros (aparecendo o General Alves Pedrosa na pasta da Agricultura, no lugar de Ezequiel de Campos, cujo nome suscitara a oposição da Associação Central de Agricultura) e com a realização do primeiro Conselho de Ministros. No entanto só a 12 de Junho, o elenco governativo ficaria completo com a posse relutante de Salazar (nas Finanças) e a posse tardia de Passos e Sousa (no Comércio).

Não era um governo coeso mas de compromisso onde se enfrentavam surdamente as duas tendências do movimento, e os problemas com que se confrontava, mais do que administrativos, eram sobretudo políticos. Ainda no dia 9 de Junho é decidida a dissolução do Parlamento sem serem anunciadas e marcadas novas eleições, numa clara violação das disposições constitucionais, o que acentua decididamente a tendência ditatorial do novo poder, e enfraquece a posição que nele continua a ocupar a tendência de Cabeçadas, em quem os partidos vêm o 
último arrimo de legalidade. Mas no dia 14, o General Gomes da Costa apresenta em Conselho de Ministros um Programa de Acção ( ${ }^{8}$, , que preconiza medidas de alteração do regime num sentido mais presidencialista e de representação corporativa: seriam suprimidos os art. ${ }^{3} 7$ e 54 da Constituição, alargadas as competências e o mandato do Presidente da República, sendo da sua responsabilidade a escolha dos Secretários de Estado; por outro lado, ao lado de uma Câmara de Municípios passaria a figurar uma Câmara de Corporações, sendo a representação feita por delegação directa dos Municípios, Uniões Económicas e corpos educativos e espirituais, «com exclusão absoluta do sufrágio individualista e consequente representação partidária» $\left({ }^{9}\right)$. Era a ruptura definitiva com o parlamentarismo e o partidarismo do sistema de governo da 1. ${ }^{a}$ República, que gera a mais viva controvérsia entre as duas alas ainda representadas, embora desigualmente, no Governo. Mas é só a 16, com nova proposta de Gomes da Costa, sobre algumas providências desejadas pelo Exército, que o conflito deflagra abertamente. Como Cabeçadas se recuse a aceitá-las, é deposto a 17 de Junho por Gomes da Costa.

Cabeçadas não deixou o governo sem tentar ainda derradeiramente preservar o já débil elo entre a Constituição e a Ditadura, procurando reservar a entrega da demissão para o Conselho de Ministros, já que, segundo disse à imprensa, «a plenitude do poder executivo está nas mãos dos ministros, que terão de resolver este caso» $\left({ }^{10}\right)$. Mas em vão: acabou por ceder às exigências de Gomes da Costa. Prevalece assim definitivamente o carácter revolucionário do levantamento. Consuma-se desse modo, por completo, a ruptura constitucional, e instaura-se definitivamente a Ditadura.

Com efeito, assim o explica o próprio Gomes da Costa. Em nova proclamação ao país, justifica-se: «Ao assumir o comando do Exército Nacional em armas, jurei bater-me pela Pátria contra os seus inimigos e pela República contra os seus políticos. Não podendo estes vencer-me no campo de batalha, tentaram fazê-lo adentro do Terreiro do Paço, com a mais vil das hipocrisias». Por isso «em nome da Pátria» se levanta de novo "para de vez reabilitar, dignificar e nacionalizar a República» (sublinhado nosso) ( $\left.{ }^{1 \mathrm{X}}\right)$. E em carta circular aos $\mathrm{Mi}-{ }^{*}{ }^{(*)}$

$\left.{ }^{8}\right)$ Consta que redigido por $\mathrm{H}$. Trindade Coelho.

(*) João Ameal (dir.), ob. cit., p. 148.

(10) Idem, p. 185.

C11) Idem, p. 179. 


\section{Revoltas e Revoluções}

nistros diz também que se decidiu pela «concentração da autoridade», pelo "uso da força», e que «dispensa o consenso do Sr. Comandante Cabeçadas» por este se ter recusado à conciliação e se ter deixado "perturbar e manietar por influências hostis ao Movimento revolucionário que o Exército levou a efeito com este objective único: a dignificação da Pátria e a reabilitação da República» $\left({ }^{12}\right)$.

Empossado Gomes da Costa na presidência do Ministério nesse mesmo dia 16, são substituídos nos dois dias seguintes os ministros que sairam. Para o lugar de Mendes dos Remédios entra Ricardo Jorge (Instrução), para o de Salazar é chamado Filomeno da Câmara (Finanças), as Colónias são ocupadas pelo Comandante Gama Ochoa e a pasta do Interior é entregue a António Claro. Nas restantes pastas permanecem Carmona, Jaime Afreixo, Alves Pedrosa, Passos e Sousa e Manuel Rodrigues. E a 26, por um decreto que atribui ao Presidente do Conselho de Ministros, provisoriamente, todas as prerrogativas de Presidente da República, Gomes da Costa passa também a ser Chefe de Estado.

A confirmar a tendência ditatorial do novo curso e do novo Governo, estão também as prisões de alguns dirigentes partidários (Helder Ribeiro, Álvaro Poppe, Álvaro de Castro, Sá Cardoso, Dias Ferreira), realizadas nos finais desse mês de Junho, a que conseguiu escapar porém José Domingos dos Santos.

\section{2. ...de nacionalização da República}

Muitos dos observadores viam com razão, aumentar a influência de políticos monárquicos no processo revolucionário, enquanto se enfraquecia o peso dos republicanos. A confirmá-lo está a remodelação governativa empreendida por Gomes da Costa a 7 de Julho, produzida no seguimento do conflito que levou à exoneração do governo de Carmona (Estrangeiros), Gama Ochoa (Marinha) e António Claro (Interior), e com os quais se solidarizaram, abandonando as respectivas pastas, todos os restantes ministros, à excepção de Filomeno da Câmara. Com efeito, tomam conta da pasta dos Estrangeiros e das Colónias, respectivamente, duas conhecidas figuras monárquicas: Martinho Nobre de Melo e João de Almeida, tendo o primeiro, entre as suas primeiras medidas, demitido significativamente

(12) Idem, pp. 182-183. 
Afonso Costa de Presidente da Delegação Portuguesa à Sociedade das Nações.

À instrumentalização do movimento pelos «políticos»partidários e parlamentares, invectivada por Gomes da Costa, segue-se assim a instrumentalização do mesmo pelos «monárquicos», que preocupa compreensivelmente os que apenas the atribuíram o propósito de nacionalização da República.

A reacção às demissões do Governo não se fez esperar. Logo no dia 8, os comandantes das guarnições de Lisboa apresentaram-se no Palácio de Belém manifestando a sua discordância pelo sucedido, sugerindo como conciliação que, Gomes da Costa, de futuro, permaneça, sem outras pastas, na chefia do Governo, mas sem voto nas suas decisões. Como encontraram a mais viva resistência por parte de Gomes da Costa, decidem intervir militarmente, depondo-o pela força, e nomeando um novo Governo, na madrugada do dia 9 de Julho. Gomes da Costa que apelou ainda iludido para as guarnições que julgava estarem-lhe fiéis, acabou por ceder no dia seguinte, sendo preso e deportado em seguida para os Açores, para onde partiu no dia 11 .

Carmona é assim colocado pelo Exército na presidência do novo Ministério, que, além de Manuel Rodrigues, Jaime Afreixo, Passos e Sousa e Alves Pedrosa, que se mantêm nas pastas que antes ocupavam, vê aparecer Ribeiro Castanho no Interior, Sinel de Cordes nas Finanças, o General Silvério Botelho na Instrução, o Dr. Bettencourt Rodrigues nos Estrangeiros e o Com. João Belo nas Colónias. Com a transição, meses mais tarde, de Passos e Sousa para o Ministério da Guerra, entrou a substitui-lo no Comércio o Major Carvalho Teixeira.

Parecia ter-se assim estabilizado o movimento e reunido condições de sólida governação para enfrentar os difíceis problemas administrativos, financeiros, económicos e sociais em que o País se encontrava mergulhado. A confirmá-lo estaria a designação de Carmona como Presidente da República pelo Conselho de Ministros ainda em 16 de Novembro de 1926 e a respectiva posse no dia 29 seguinte. Mas a contraditá-lo estavam também o recrudescer de pequenas tentativas insurrecionais, de cariz democrático-republicano uma (ocorrida em Chaves), de feição monárquica outra (que levou à prisão e julgamento de João de Almeida).

Mas mais clarividente sintoma dessa periclitante estabilidade foi a ameaça dos partidos do anterior quadro parlamentar, entregue nas Legações diplomáticas acreditadas em Lisboa, em Janeiro de 1927, de que considerariam nulos os acordos e operações financeiras que o actual Governo procurava negociar e assinar, se, como tudo fazia prever, não fossem sancio- 


\section{Revoltas e Revoluções}

nados pelas Câmaras. A oposição democrática, talvez encorajada com o refreamento das tendências monarquizantes de radicalização integralista do movimento, reaparecia, e com força e credibilidade bastantes para tentar condicionar externamente os movimentos do Governo. Era o prenúncio de uma reaç̧ão mais organizada que viria efectivamente a desencadear-se nos começos de Fevereiro, e com vasta expressão militar.

No dia 3, revoltam-se no Porto o General Sousa Dias, o Comandante Jaime de Morais, o Capitão Sarmento Pimentel, ao lado dos quais estão políticos importantes como Jaime Cortesão e José Domingos dos Santos. E a 7 do mesmo mês, o levantamento estende-se a Lisboa, sob o comando do $1 .^{\circ}$ Tenente da Marinha Agatão Lança. Os revoltosos pretendiam o derrube do Governo e o regresso à normalidade Constitucional. Depois de alguns dias de luta encarniçada, as forças governamentais, chefiadas pelo Ministro da Guerra Passos e Sousa subjugariam a insurreição, que deixou no terreno mais de uma centena de mortos, algumas centenas de feridos e inúmeros estragos.

A vitória sobre as forças democráticas reanimou por seu turno as tendências mais radicalizantes do movimento do 28 de Maio, que começaram por aproveitar a cada vez mais sentida necessidade de criação de um movimento político de apoio ao Governo da Ditadura, para tentar imprimir novo rumo ao curso da Revolução.

Com efeito, uma vez consolidada militarmente, a Ditadura começa também a pensar na sua consolidação política. Pretendia neutralizar os ataques políticos dos partidos afastados da cena, mobilizando publicamente um suporte de legitimação e de nova constitucionalização. Surgiu assim a ideia de congregar numa força política os partidários da Revolução.

Encarregou-se de a lançar um jornal, publicamente conhecido como órgão «oficioso» da Ditadura - o Portugal — dirigido pelo Ten. Cor. Pestana de Vasconcelos (13). Num editorial entitulado «Organizemos a Era Nova» era feito o apelo «no sentido de se organizarem convenientemente as boas vontades» hoje dispersas, e que em tão grande número se achem dispostas a apoiar o Exército e o Governo da Ditadura Militar para a estabilidade e a continuidade na sua profunda e formidável obra de renovação $\left({ }^{14}\right)$.

(13) O Portugal fora lançado a 23 de Agosto de 1926 como «Diário da Manhã», de orientação republicana.

(14) Portugal, 26 de Novembro de 1926. 
A reacção não se fez esperar, e cedo chegam à redacção do jornal inúmeros apoios e adesões à iniciativa, como cedo também desencadeiam reparos, críticas e oposições. Alguns redactores do Portugal expõem em conferências pela província, a convite das guarnições militares locais, «os fins da organização civil exigida pelo país com o beneplácito da Força Armada» $\left({ }^{15}\right)$.

A iniciativa de «oficiosa» torna-se «oficial» quando Carmona, a 1 de Fevereiro de 1927, anuncia que «o Governo, sentindo que a opinião pública está a seu lado, entendeu também que era a altura de se criar uma força civil poderosa e disciplinada em cujas mãos possa confiar um dia os destinos da Nação». E avisa que o Governo em breve lançará um manifesto ao país para dar «conta desse seu pensamento» $\left({ }^{16}\right)$.

Em finais de Fevereiro, efectivamente, o embrião da nova organização, que se convenciona chamar Milícia Nacional tem já comissões encarregadas de dar esclarecimento em quase todas as freguesias de Lisboa, e apoios organizados nalguns pontos da província. E a 25 de Fevereiro tem lugar em Lisboa a primeira reunião dos organizadores da Milícia para lhe fixar as bases gerais. Estão presentes delegados do Norte $\left({ }^{17}\right)$ e a Comissão Organizadora de Lisboa. Determinam-se-lhe os princípios regulamentadores de acção e de propaganda. E a 20 de Março de 1927, numa reunião a que preside o Coronel Vicente de Freitas, são empossados a «Comissão para a Organização Civil» e uma anexa Federação Nacional Académica ${ }^{18}$ ).

Apesar de tudo a iniciativa não é clara e deixa em aberto uma série de interrogações e dúvidas sobre a sua natureza, propósitos, funções, e relações com as forças armadas como «Milícia». Os hipotéticos apoios são regateados em face da imprecisão da iniciativa, o que obriga o Governo, pela voz do Ministro da Guerra Passos e Sousa, a vir a público precisar: «O assunto não tem sido tratado com o cuidado que requeria. Não se entrou em alguns detalhes indispensáveis. A milícia que, afinal, tenhamos a coragem das palavras, é uma organização política, representa o projecto que um certo número de amigos da actual situação entregou ao Governo». Para tran-

(15) Portugal, 9 de Dezembro de 1926.

(16) Portugal, 1 de Fevereiro de 1927.

(17) Onde sobressai a figura bracarense do Dr. Alberto Cruz.

(15) Esta organização, também designada Confederação Académica de União Nacional, tinha como Presidente o Cap. João Afonso de Miranda, como vice-presidente José Centeno Castanho (Téenico) e José Duarte Ayala Boto (Medicina). Entre os seus vogais figurava o quintanista de Direito Marcelo Caetano. Esta direcção foi recebida por Carmona, na companhia de Vicente de Freitas e Pestana de Vasconcelos (Cf. Portugal, 24 e 25 de Março de 1927). 


\section{Revoltas e Revoluções}

quilidade dos republicanos, acrescenta que a milícia será «independente de fórmulas governativas», mas que «tudo será feito dentro do regime republicano, e sob a sua égide». E para serenamento de monárquicos, afirma ainda que «o projecto há-de estudar-se e modificar-se de maneira a que caibam dentro da nova organização todas as pessoas que apoiam o actual estado de coisas» $\left({ }^{19}\right)$.

De facto a natureza miliciana da nova organização política incutia as mais sérias reservas aos republicanos liberais, que não aceitavam a ideia da criação de milícias, porque seriam «paradoxais como corpo policial ou de manutenção da ordem pública, numa situação exclusivamente militar», e porque «seriam um partido político, armado até aos dentes, sem objectivos concretos e definidos, sem chefes de prestígio e sem função reorganizadora da sociedade» $\left({ }^{20}\right)$.

Por seu turno, os monárquicos legitimistas de $A$ Voz, embora aceitando a necessidade de uma união de esforços civis à volta do Governo da Ditadura, punham reparos à pretendida natureza republicana da organização e ao seu possível carácter partidário. «Não será, seguramente, ofendendo os sentimentos de boa parte da Nação, a que muito deve a causa da ordem» que se realiza «digna e frutuosamente essa missão», além de que «a Ditadura não precisa de partidos para nada». «Por isso - acrescentam — acolhemos com certa reserva todas as notícias, em que se fala da organização civil da Ditadura» $\left({ }^{21}\right)$.

Passos e Sousa vinha sublinhando, de facto, algo enfaticamente, que «a organização política destinada a apoiar a Ditadura tem que ser, fatalmente, sem subterfúgios, com toda a clareza, uma organização republicana, vincadamente republicana. É preciso que ninguém esqueça que estamos em República - e que defendemos a República sem uma única transigência quanto ao regime». E sugeria mesmo que «a solução política nacional seria a reconstituição e depuração das forças republicanas agremiadas em dois partidos fortes: um conservador, outro radical. Cada um teria a sua vez de Governar» (22).

(19) A Situação 7 de Março de 1927.

(20) A Situaçâo, 17 e 20 de Abril de 1927. A Situação fora fundado em 1917 como suporte do sidonismo. A segunda série surgira em 1927 sob a direcção de Botelho Moniz, da União Liberal Republicana de Cunha Leal. Apoiou o Ten. Cor. Passos e Sousa contra as pressões monárquicas. Pretendendo-se independente da ULR viria efectivamente a demarcar-se de Cunha Leal em Dezembro de 1927, quando Botelho Moniz se viu forçado a abandonar o partido para continuar à frente do jornal, por apoiar, contra as directrizes da ULR, o pedido de empréstimo de Sinel de Cordes à Sociedade das Nações.

(21) $A$ Voz, 9 e 22 de Março de 1927.

(22) A Situação, 11 de Julho de 1927. 
Os monárquicos sentiam-se excluidos deste projecto, que acabavam por recusar: «Pensar em remodelação dos partidos, em novas arrumações das forças partidárias, em criar o rotativismo republicano como por aí alvitram certos defensores dos políticos que o Exército afastou do poder, seria um erro muito grave, de consequências as mais nefastas» (23). Mais: era preciso urna nova organização da representação nacional e do sufrágio, que seria directo apenas para as assembleias de freguesia. "Qualquer que seja a organização política que venha a esboçar-se ela só conseguirá evitar a queda nos velhos erros, e consequentemente o regresso aos antigos vícios, se eliminar o sufrágio como base de ascenção ao poder» $\left({ }^{24}\right)$.

Mau grado o apoio recebido pela Confederação Patronal e pela Cruzada Nun'Alvares $\left({ }^{25}\right)$, a ideia da organização cívica, sob a forma de Milícia Nacional, tão encorajada por alguns oficiais e sectores monárquicos mais radicais entre os quais se destacava o Tenente Morais Sarmento (26) acabaria por não vingar, pela ausência de consenso não só entre importantes correntes de opinião que apoiavam a ditadura como entre membros do próprio Governo.

Acabou por comprometer a ideia de um modo especial o malogro do chamado «Golpe dos Fifis» em Agosto de 1927 onde estiveram envolvidos alguns dos seus mais conhecidos entusiastas, entre os quais o próprio Tenente Morais Sarmento.

De facto a clivagem entre apoiantes monárquicos e republicanos da Ditadura reacentuara-se depois do 7 de Fevereiro, e vai conhecer particular acuidade após a publicação do Manifesto do Governo ao país, por ocasião do primeiro aniversário do 28 de Maio, onde se fala da intenção de separar os cargos de Presidente da República e Presidente do Conselho de Ministros, acumulados por Carmona desde finais de Novembro de 1926. A luta pela sucessão de Carmona na chefia do Governo estava, a partir de então, aberta: de um lado os republicanos escudados na pessoa de Passos e Sousa; do outro os monárquicos mais radicais que apoiavam a figura de Filomeno ? da Câmara.

Nos primeiros dias de Agosto vai-se tornando pública a ideia da designação de Passos e Sousa como vice-presidente do Ministério. A 12 desse mesmo mês, uma parte do Exército de

C) A Voz, 4 de Maio de 1927. Fora de facto A Cidade que lançara a ideia de se criar um rotativismo político em alternância, que mereceu a concordância de A Situação (17 e 20 de Abril de 1927).

(24) A Voz, 5 de Setembro de 1927.

(25) Portugal, 24 de Março de 1927.

C) $O$ Tenente Morais Sarmento defendera a Milícia em $A$ Voz (6 de Março de 1927 como «organismo de mobilização» de «carácter permanente e vastíssimo». 


\section{Revoltas e Revoluções}

simpatia monárquica pressiona para que a Vice-Presidência seja antes entregue a Filomeno da Câmara. O Tenente Morais Sarmento, conhecido pelas actividades organizadoras da Milícia Lusitana, distribuiu um Manifesto nesse sentido pelos quartéis, preparando um pressionamento pela força. Mas um desentendimento com o Capitão Daniel Neto fez gorar os planos de imposição militar de tal solução. Por seu turno, o próprio Filomeno da Câmara, acompanhado de Fidelino de Figueiredo, tentam junto da Imprensa Nacional a publicação de um diploma de demissão do Governo e de nomeação de Filomeno da Câmara como Ministro, concentrando provisoriamente todas as pastas. Mas igualmente sem êxito. Acabam por ser todos presos ao cair desse dia 12, juntamente com os demais implicados, vindo os «fifis» a ser deportados a 15 para S. Tomé. Gorava-se assim de novo a radicalização monarquizante que o golpe procurava dar ao movimento, tal como acontecera com a acção que levou à deposição de Gomes da Costa. Desse modo enfraquecia-se de novo a componente monárquica no seio dos apoiantes da Ditadura e reforçava-se de novo a componente republicana, o que contribuiu decididamente para o fracasso da Milícia.

Por isso, o novo Governo empossado a 26 de Agosto, onde Vicente de Freitas (outrora ligado à formação da Milícia) passa a ocupar a pasta do Interior, vai chamar a si a iniciativa de relançar a ideia da organização política mas sob nova forma. Será a União Nacional Republicana.

A 30 de Setembro de 1927, o Governo decide, com efeito, em Conselho de Ministros, apoiar a «formação da União Nacional, organização das forças civis que apoiam a Ditadura Militar», sublinhando a necessidade de «contrapor à orgânica dos partidos políticos... uma organização que aglomere e ligue a enorme massa dos portugueses que não querem o retorno ao passado» $(27)$.

É na altura confiado o «estudo das bases em que assentará a referida organização civil» a uma comissão integrada pelos Ministros das Finanças, da Justiça e do Interior, respectivamente Sinel de Cordes, Manuel Rodrigues e Vicente de Freitas. Essa comissão torna público o resultado dos seus primeiros trabalhos a 30 de Outubro, apresentando o seguinte plano de acção:

«1. ${ }^{\circ}$ - Aceitar a colaboração dos indivíduos e das organizações que desinteressada e voluntariamente desejem trabalhar para o prestígio das instituições, para o bem-estar e progresso do país e para a defesa da ordem;

(27) João Ameal (dir.), ob. cit., vol. II, pp. 107-108. 
2. ${ }^{\circ}$ - Organizar em cada Concelho um núcleo para agregar os elementos que desejem colaborar na obra da Ditadura è sirva de órgão transmissor, para o Distrito, das aspirações e necessidades locais;

3. $\quad$ - Criar em cada Distrito um organismo que centralize e transmita ao Governo as aspirações e necessidades distritais;

$4 . \quad \circ-$ Promover para época a fixar um Congresso Municipalista, no qual sejam tratados os problemas mais instantes relativos aos Municípios».

No final desse ano, correm rumores de que o Governo começara a preparar a eleição presidencial de 1928. Vicente de Freitas, numa entrevista ao Diário de Notícias a 27 de Dezembro, confirma que está em estudo uma nova lei eleitoral, de cuja elaboração foram ele próprio e Manuel Rodrigues encarregados, e revela ter expedido uma circular a todos os governadores civis, ordenando-lhes o início dos trabalhos de recenseamento em Janeiro, por um período de mês e meio, a fim de dar lugar às eleições presidenciais, na segunda quinzena de Fevereiro, e, de seguida, às eleições administrativas. Para ambas contará a Ditadura «com as forças da União Nacional Republicana, cuja organização está também concluída até ao fim de Fevereiro», já que a organização «progride de uma maneira admirável, com adesões entusiásticas de todos os pontos do país». «Uma vez feita a União Nacional iremos para as eleições de municípios». De facto, o mesmo Ministro do Interior percorre vários distritos em Janeiro e Fevereiro de 1928 «a tratar de assuntos que se prendem com a próxima eleição presidencial e com a organização da União Nacional Republicana», no dizer da imprensa, que chega a apresentar nomes de membros de algumas das suas Comissões locais. A iniciativa, porém, parece não ser bem sucedida e cai temporariamente no esquecimento. "A partir de meados de Fevereiro - segundo o relato que temos vindo a seguir $\left({ }^{28}\right)$ - perde-se completamente o rasto da falada União Nacional Republicana e as deslocações do Ministro do Interior, noticiadas pelos jornais, já só se reportam à «próxima eleição presidencial», parecendo ter-se parado de todo a ideia de formar um agrupamento político com aquela designação. Talvez esteja relacionada com o fracasso desta iniciativa a criação - anunciada nos jornais de 29 de Fevereiro - duma Comissão de Propaganda da Ditadura,

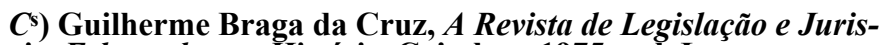
prudência. Esboço da sua História, Coimbra, 1975, vol. I. 


\section{Revoltas e Revoluções}

com fins parcialmente coincidentes com os da projectada União Nacional Republicana, e de cuja actividade há frequentes notícias nos jornais de Março»».

Da mesma maneira, o aparecimento em finais de 1927 da Liga Patriótica 28 de Maio, igualmente criada para realizar a unidade nacional e desenvolver num sentido acção política e de «regeneração social», e que mereceu, o apoio monárquico negado à União Nacional Republicana é um indicador de falência deste último $\left({ }^{29}\right)$.

Quer a iniciativa da Milícia, quer a da União Nacional Republicana, gorar-se-iam assim pela oposição que encontraram, mais por parte do sector republicano a primeira, mais por parte do sector monárquico a segunda.

A ditadura debatia-se assim com o difícil equilíbrio entre os apoios monárquicos e republicanos que lhe eram dados. Procurando manter as instituições típicas do quadro republicano, nomeadamente a eleição do Presidente da República, mas fazendo-o por sufrágio directo, e libertando o cargo de responsabilidades governativas, realizava-se, pelo compromisso, o difícil equilíbrio entre o desejo republicano de sancionar popularmente a escolha de chefia da Nação com o propósito monárquico de a libertar da dependência parlamentar e das tarefas governativas, e de lhe conferir cada vez mais funções de poder moderador.

A eleição de Carmona para a Presidência da República por sufrágio directo, embora restrito, ocorrida a 25 de Março de 1928, e o seu abandono definitivo da chefia do Governo, após a posse do cargo em Abril seguinte, vieram corporizar o desfecho dessa tensão, nunca de todo eliminada ao longo do Estado Novo, entre republicanos e monárquicos.

\section{Conciliação religiosa não confessional}

Se a clivagem entre monárquicos e republicanos foi de particular importância na formação do Estado Novo, não o foi menos a existente entre católicos e laicos.

A República, querendo combater o clericalismo com o jacobinismo, afrontara a consciência religiosa da maioria dos portugueses. A questão religiosa, apesar de passos importantes dados no sentido da sua revolução, estava ainda em aberto a 28 de Maio de 1926. Por isso, logo nesse dia, os revoltosos mi-

$\mathrm{C}^{28}$ ) Sobre a Liga 28 de Maio, cf. António Costa Pinto, «Da Ditadura Militar ao Estado Novo de Salazar: fascismo e autoritarismo em Portugal nos anos 30» (em publicação in Ler História, n. ${ }^{\circ}$ 5). 
litares se propuseram enfrentá-la com intuito de congregar os apoios católicos para a nova situação, sem afrontar porém o laicismo republicano.

Ainda em Braga, no próprio dia 28 de Maio, quando decorria por coincidência a peregrinação nacional ao Sameiro, Gomes da Costa aproveitou a circunstância para garantir às autoridades religiosas o respeito pelas cerimónias. E dias depois, ao chamar para o primeiro Governo dois prestigiados dirigentes do Centro Católico (Salazar e Mendes dos Remédios), manifestava a clara disposição de cooptar os católicos organizados, e com eles a hierarquia, para o poder que pretendia consolidar.

Mas foi sobretudo com o reconhecimento legal da «personalidade jurídica» à Igreja Católica, promulgado ainda sob a liderança de Gomes da Costa, que a Ditadura revelou querer procurar um novo tipo de relações com a Igreja. O decreto de 7 de Julho, da autoria do Ministro Manuel Rodrigues mereceu porém ainda reservas e críticas do lado católico, expressas aliás publicamente pelo próprio Salazar. A «personalidade jurídica», com efeito, era reconhecida não às paróquias e dioceses, mas sim às "corporações encarregadas de culto». Por outro lado, não se extinguia com ela a «Comissão Central da Lei de Separação» que, pelo contrário, se mantinha com outro nome $\left({ }^{30}\right)$.

Isso não impedia porém que os católicos do Centro, dessem ao Governo da Ditadura uma apreciável colaboração técnica, nomeadamente através de Salazar (na Comissão de Reforma Tributária, criada ainda em Julho de 1926 por Sinel de Cordes) e de Mário de Figueiredo (na Comissão encarregada pelo mesmo Ministro das Finanças de negociar, com o governo inglês, o pagamento das dívidas de Guerra, e na delegação portuguesa à Conferência Económica Internacional da Sociedade das Nações). E bem depressa esse «estar com o Governo» se converteu num «estar no Governo».

Com a eleição de Carmona e o seu abandono da chefia do Governo, novo Ministério é empossado a 18 de Abril de 1928 presidido por Vicente de Freitas. Salazar que se evidenciara com a publicação de uma série de artigos de crítica à política financeira de Sinel de Cordes nas páginas do Novidades, é instantaneamente convidado e acaba por aceitar, tomando conta do lugar a 28 de Abril desse ano.

A entrada de Salazar para o Governo traduziu um importante compromisso entre a Ditadura e a Igreja. Como o próprio Salazar confessará mais tarde, «o Sr. Presidente do

${ }^{30}$ Manuel Braga da Cruz, As origens da democracia cristã e o Salazarismo, Lisboa, Presença, 1980, pp. 354-355. 
Ministério só obteve a minha aquiescência a colaborar com ele no Gabinete, tomando comigo o compromisso formal de que o Ministério de que eu fizesse parte não adoptaria qualquer medida que violasse os direitos concedidos por leis ou governos anteriores aos católicos» (31). Por seu turno, Vicente de Freitas pediu a Salazar que não tocasse no regime de separação ( ${ }^{32}$ ).

Não se tratava porém de um mero acordo entre personalidades, mas de um entendimento institucional. Consta, de facto, que não terá sido alheio à indicação de Salazar o própro episcopado. Em contrapartida, com a entrada de Salazar para o Governo foi desactivada a preparação do iminente III Congresso do Centro Católico, previsto para esses dias, e que acabaria por ser indefinidamente adiado, onde se admitia viessem a ser formuladas as reivindicações a apresentar ao Governo em matéria de política religiosa. Por outras palavras, a Igreja, através do Centro Católico, renunciava à reivindicação imediata das pretensões que haviam feito nascer o próprio Centro, em troca da ocupação da principal pasta do Governo por um dos seus membros mais eminentes.

Mas à entrada de Salazar seguiu-se a de Mário de Figueiredo para a pasta da Justiça, a 10 de Novembro desse ano de 1928, que publicou a 29 de Junho do ano seguinte uma portaria autorizando a realização de procissões e o toque dos sinos. O documento provocou a viva controvérsia entre os republicanos laicos, adeptos da Ditadura, e por essa razão, acabou por ser revogada pelo Conselho de Ministro, dias depois, o que motivou o pedido de demissão de ambos os ministros "católicos». Abria-se assim uma grave crise política com o caso da «portaria dos sinos».

Novo Governo é empossado a 8 de Julho, agora presidido por Ivens Ferraz. Nos Negócios Estrangeiros aparece Trindade Coelho, embaixador no Vaticano, e Salazar reaparece nas Finanças, justificando que não se demitira tal como Mário de Figueiredo por causa da votação no Conselho de Ministros que anulou a portaria, mas porque «a revogação da portaria citada reconheceu como boas certas práticas restritivas de direitos concedidos 'por leis anteriores'» $\left.{ }^{33}\right)$, violando desse modo o compromisso assumido aquando da sua posse. Reentrando no Go-

(31) In Damião Peres, História de Portugal, Barcelos, I Suplemento, p. 457. Cf. também Guilherme Braga da Cruz, ob. cit. $f$ p. 793, nota 1598 . Verbo, 197, p. 39.

(32) Marcelo Caetano, Minhas memórias de Salazar, Lisboa,

(33) Cf. João Ameal (dir.), ob. cit., vol. II, p. 296. 
verno de Ivens Ferraz estava implicitamente a renovar esse acordo institucional entre a Igreja e a Ditadura, e a consagrar, dessa forma, um modus vivendi que viria anos mais tarde a concordatar formalmente em nome do Estado Novo com o Vaticano, e que consistia basicamente na manutenção do regime de separação mas dando em contrapartida à Igreja Católica um tratamento deferencial e privilegiado.

Evitava-se assim com esse compromisso não só a reabertura da questão religiosa, tal como antes se evitara a da questão do regime, mas também veleidades de confessionalização do regime. O Estado Novo não seria um «nacional-catolicismo», mas a sua laicidade não o impediria de reconhecer a religião e a Igreja Católica como factores importantes de estabilização social, e a missionação como factor importante de colonização.

É a essa luz que pode ser lida também a passagem de Salazar pela pasta das Colónias, para onde entrou nos começos de 1930 e saiu em finais de Julho, assinalada pela publicação do Acto Colonial.

\section{Um regime com partido único}

Depois de frustradas tentativas anteriores de lançamento de uma organização civil de apoio político à Ditadura, foi finalmente anunciado pelo Governo o lançamento da União Nacional a 30 de Julho de 1930.

A União Nacional surge quando a Ditadura Militar, quatro anos volvidos sobre a sua instauração, se propõe resolver o problema político ainda em aberto, plebiscitando-se e tomando-se regime constitucional. Salazar, no famoso discurso da Sala do Risco, a 28 de Maio desse ano, dissera claramente aos militares que o foram cumprimentar que a Ditadura não era solução, e que importava resolver o problema político «por meio de uma obra educativa que modifique os defeitos principais da nossa formação, substitua a organização à desorganização actual e integre a Nação, toda a Nação, no Estado, por meio de novo estatuto constitucional» $\left({ }^{34}\right)$.

Foi de facto por isso e para isso que a criação da União Nacional foi anunciada pelo Governo da Ditadura a 30 de Junho de 1930, numa reunião em Lisboa para a qual convocou expressamente governadores civis e autoridades municipais. Aí se definiu desde logo a natureza e as funções cívicas e políticas que eram cometidas à organização, num Manije sto $>$ do Governo

C ${ }^{34}$ ) Salazar, Discursos, Coimbra Editora, vol. I, p. 65. 
apresentado pelo Presidente do Ministério General Domingos de Oliveira, e após cuja leitura usaram também da palavra o Ministro do Interior Lopes Mateus e o Ministro das Finanças Oliveira Salazar.

A União Nacional vinha assim preencher o vazio político deixado pela dissolução do Congresso da República, decretada a 9 de Junho de 1926, e pela neutralização progressiva da Constituição de 1911, feita sobretudo através da restrição das liberdades públicas de reunião, associação e informação. As organizações partidárias e sindicais de outrora, se não formalmente proibidas, estavam porém praticamente dissolvidas e controladas.

Com o anúncio público da União Nacional, o Governo apelou às forças nacionalistas (monárquicas constitucionais e integralistas, católicos centristas, republicanos e liberais conservadores) para se congregarem à sua volta para o secundar política e civicamente, no seu desígnio legitimador e constituinte.

De acordo com o programa de lançamento, traçado pelo Ministro Lopes Mateus, a União Nacional começou a implantar-se pelo país. O Governo constituiu «comissões promotoras» nas capitais de distrito e nas sedes de concelho, por indicação directa do Ministro do Interior, após informações prestadas pelos Governadores Civis e pelos administradores de concelho. Nos finais de 1930, o Governo mostrava-se já satisfeito com o ritmo de instalação da organização e com a amplitude dos apoios recebidos.

As inscrições na União Nacional começaram efectivamente a verificar-se nesses primeiros meses, embora ainda a um ritmo lento. Só em 1931 atingiram um número já avultado, e entre elas figuravam efectivamente antigos inscritos nos partidos da Primeira República, desde os mais moderados até aos mais radicais. O ano de 1930 será, porém, sobretudo, o ano da constituição dos quadros directivos, quer centrais quer regionais.

A 18 de Maio de 1931 reunem-se pela primeira vez em Lisboa, convocados pelo Ministro do Interior, os representantes das Comissões da União Nacional que aprovam, juntamente com as autoridades govemativas que as haviam nomeado para elas, as Bases Orgânicas provisórias, e elegem a primeira, embora também provisória, Comissão Central.

As Bases Orgânicas provisórias reafirmam os princípios doutrinários já expressos no Manifesto do Governo de 1930: o carácter político cívico mas não partidário da organização, porque sem competência para o exercício do poder. E estabelecem também normas para a designação provisória dos primeiros 
órgãos directivos. A primeira Comissão Central é presidida pelo Presidente da Comissão Distrital de Lisboa, Sampaio e Melo.

Ao longo desse ano de 1931 a União Nacional promove manifestações e sessões públicas de apoio ao Governo e à Revolução Nacional, dando desse modo uma primeira ideia das funções a que prioritariamente os fundadores a votaram. Mas no ano seguinte, é orientada pelo Governo para a preparação da «normalidade constitucional» e do «novo direito público português»), isto é para a preparação da aprovação e funcionamento da nova Constituição e para a aplicação do novo direito administrativo, e da nova legislação eleitoral e corporativa.

Quando a União Nacional se constituiu pairavam ainda dúvidas sobre o sistema de governo e partidário que a nova ordem constitucional consagraria. $\mathrm{O}$ anúncio, feito repetidamente pelos autores do 28 de Maio, da intenção de manter o regime republicano e de nele continuar a recorrer a processos eleitorais e de nele assegurar um sistema representativo, fazia acalentar nalguns sectores esperanças de restauração do pluralismo partidário, ou pelo menos de instauração de um muito falado rotativismo bipartidista, no qual a União Nacional viria a ser um dos pólos.

Bem depressa se desvaneceram tais ilusões, com a progressiva afirmação do mono-partidarismo, primeiro aquando do anúncio das primeiras eleições administrativas em 1931, e depois com a apresentação e plebiscitação do novo texto constitucional em 1932 e 1933.

A oposição, reunida em tomo da Aliança Republicana e Socialista, pretendeu obter do Governo, após o anúncio das eleições de 1931, garantias de liberdade de concorrência às urnas. A resposta dada pelo Governo prefigurou desde logo o sistema constitucional que viria a vigorar: a oposição teria liberdade de actuação, desde que não atacasse a Ditadura. Sem lhe negar teoricamente o direito a existir, condicionava-se-lhe a organização e actuação, com um estatuto de subalternidade. Seriam consentidas «correntes de opinião» mas não partidos políticos, como- precisaria o Ministro do Interior, já que os partidos haviam sido até 1926 - segundo a acusação do primeiro Manifesto ao país da União Nacional a 12 de Julho de 1931 - um «cancro vivendo ao lado da Nação e contra ela», «associações de exploração do Estado» (35), opinião que era repetida pouco depois pelo Presidente Carmona, ao acusar numa entrevista os partidos de serem «compostos por maus portugueses, que levaram anos a ludibriar o país, fazendo-lhe promessas que nunca cumpriram,

(35) Diário da Manhã, 12 de Julho de 1931. 


\section{Revoltas e Revoluções}

com o único fím de captar adesões e aumentar prosélitos, sustentando-os à custa do Estado» $\left({ }^{36}\right)$.

Os mesmos propósitos são confirmados no ano seguinte, com a publicação pelo Governo, respectivamente a 27 e 28 de Maio, dos Estatutos da União Nacional e do projecto de nova Constituição. Numa longa e importante introdução aos Estatutos reafirma-se a natureza antipartidária e apartidária da União Nacional, justificando-a pela natureza do novo regime constitucional e do novo parlamento, de onde desapareceriam os partidos. A União Nacional não seria por isso um partido, por não ambicionar para si ou para os seus compromissos o poder, que seria exercido pela Nação organizada.

$\mathrm{O}$ novo projecto de Constituição, posto à discussão pública antes de ser plebiscitado, desencadeara a oposição do sector liberal republicano dos fautores do 28 de Maio, liderado pelo então Presidente da Câmara de Lisboa General Vicente de Freitas - já presidente do Governo da Ditadura que convidou Salazar para a pasta das Finanças. Insurgindo-se contra o monopólio da representação atribuído à União Nacional pelo projecto da Constituição, Vicente de Freitas vem a público exprimir a opinião dos liberais republicanos de que o 28 de Maio se fizera contra a ditadura política de um partido: o partido democrático. A nova organização do Estado não poderia por isso vir restaurar o monopólio de outro partido, transformando assim um «monopólio de facto em monopólio de direito». A resposta do Governo, já então chefiado por Salazar, traduziu-se na demissão de Vicente de Freitas. E o projecto de 1932 que consagrava ainda a definição da República Portuguesa como «organicamente democrática e representativa», vê-se alterado neste artigo do texto plebiscitado, passando a República a definir-se «unitária e corporativa». Acabara por prevalecer a unicidade política da representação, reservada, não na teoria constitucional mas na prática administrativa, para a União Nacional.

Esta actuação do Governo de Salazar, coincide aliás com os propósitos enunciados, logo após a tomada de posse, de preparar a União Nacional para as novas tarefas constitucionais. Foi aliás nesse sentido que se constituiram e empossaram os primeiros órgãos directivos não provisórios, a 12 e 23 de Novembro de 1932, respectivamente. Numa clara intenção de pôr o Governo a presidir aos destinos da União Nacional, a Comissão Central tem como Presidente Salazar, como vice-Presidente o Ministro do Interior Albino dos Reis, sendo todos os restantes

(M) Entrevista a $A$ Voz, transcrita pelo Diário da Manhã, 11 de Setembro de 1931. 
elementos - excepção feita para Bissaia Barreto - ou actuais ou antigos membros de governos da Ditadura. Era o Governo à frente da União Nacional e não a União Nacional à frente do Governo. É no discurso da posse dessas Comissões que Salazar se dirige às «diferentes forças políticas em face da revolução nacional», convidando-as a ingressar na União Nacional, único espaço possível de actuação política consentido. «Fora da União Nacional não reconhecemos partidos, dentro dela não admitimos grupos» ( ${ }^{37}$ ), frisou então lapidarmente Albino dos Reis, a corroborar Salazar.

À posse da Comissão Central seguem-se as das Comissões Distritais, logo colocadas pelos Governadores Civis na dependência dos objectives e das estruturas governativas locais. A nova constitucionalidade não se esgotava na plebiscitação da Lei, ocorrida a 19 de Marco de 1933, com resultados pouco lisongeiros para o Estado Novo: apenas $59,7 \%$ dos votantes lhe deram voto favorável. Havia que passá-la do texto das leis nara o «espírito do país», no dizer de Salazar ( ${ }^{(38)}$. Competiria à União Nacional a criação dessa «mentalidade nova». Nesse sentido. é também criada na Comissão Central, em Outubro de 1933, a primeira Comissão Executiva, presidida por Albino dos Reis (na qualidade de Vice-Presidente da C. Central) e integrada por Marcelo Caetano e Carneiro Pacheco. E para isso se decide a realização do I Congresso da União Nacional para finais de Maio de 1934.

Não faltavam de facto pressões para imprimir cunho totalitário ao monopartidarismo, nomeadamente entre 1933 e 1935, por parte do nacional-sindicalismo. Os camisas azuis de Rolão Preto pretendiam com efeito contrapor à modorra do redime, à passividade das massas e à subordinação política da União Nacional ao governo, a carismatização da chefia, o arrebatamento popular e a mobilização de massas, a militarização do movimento e a sua afirmação na condução dos negócios do Estado. Preconizavam para a União Nacional um outro estilo político - mais miliciano e combativo - e para o regime outra legitimação - mais carismática do que tradicional e conservadora.

Tais pressões seriam porém categoricamente rejeitadas no I Congresso da União Nacional. «Se o Estado Novo não pode ser totalitário - dizia então Salazar — também «não pode sê-lo a União Nacional». Teoricamente recusava-se à União Nacional o estatuto de «partido único» em nome de uma composição aberta

(3T) Diário da Manhã, 24 de Novembro de 1932.

( $\left.{ }^{38}\right)$ Cf. João Ameal (dir.), ob. cit., vol. III, pp. 252-253. 


\section{Revoltas e Revoluções}

$e$ de funções meramente representativas e não executivas, ou como diria anos mais tarde Marcelo Caetano, funções de «colaboração cívica e não de participação política» (39). Mas reconhecia-se simultaneamente que «fora dela existem e podem sempre existir - na expressão de Salazar — pessoas a quem, tenham ou não as mesmas ideias fundamentais, são reconhecidos na Constituição e nas leis direitos políticos. O essencial é que não ofendam nem a actividade governativa nem os fins da Constituição, e isto quer dizer que, se alguns se erguem contra eles, obrigam o Estado, em legítima defesa, a limitar-lhes o exercício de faculdades que não sabem ou não podem exercer sem prejuízo da renovação nacional empreendida» $\left({ }^{40}\right)$.

Foi efectivamente o que veio a acontecer em relação ao Nacional-Sindicalismo, a quem Salazar lança dois meses depois um ultimatum: ou entram para a União Nacional ou serão considerados como indiferentes ou inimigos, não sem exorcizar os «processos políticos não sancionados pela União Nacional» que eram os dos homens de Rolão Preto.

Para além disso o I Congresso reforçou, a par da unicidade, a hierarquização e centralização directiva, mediante algumas alterações estatutárias: introdução da figura do chefe e substituição de eleição de membros directivos por simples nomeação. A par disso, doutrinariamente, é atribuída à União Nacional a função primordial não só de implementar constitucionalmente o regime, nomeadamente, as instituições previstas no texto de 1933, como também de colaborar na sua corporativização.

De facto, uma vez aprovada a Constituição, havia que institucionalizá-la. Por isso se encarrega a União Nacional de preparar a eleição da nova Assembleia Nacional, que tem lugar a 16 de Dezembro de 1934, e a eleição do Presidente da República, que ocorre a 17 de Fevereiro de 1935, bem como ainda as eleições administrativas que se realizarão em Outubro e Novembro de 1937.

A primeira campanha eleioral da União Nacional - a primeira na história do país a dispor de modernos meios de comunicação radiofónica - constituiu um teste para a organização, proporcionando simultaneamente a verificação primeira das relações entre a União Nacional e a nova Assembleia. Logo a abrir a campanha, Salazar, ao analisar «O Movimento Político» frisara que «poderão ou não pertencer à União Nacional, os deputados da Assembleia e os representantes da Câmara

(3e) Diário da Manhã, 20 de Fevereiro de 1948.

(40) Salazar, Discursos, vol. I, p. 347. 
Corporativa». A percentagem de candidatos unionistas não chega efectivamente a atingir os $50 \%$.

Por seu lado, as eleições assumem desde logo carácter plebiscitário, com a sanção legal de um colégio eleitoral de círculo único e lista única, visando explícitamente, como dizia o preâmbulo da lei eleitoral de 7 de Novembro de 1934, eliminar a «competição política, elemento perturbador de todas as assembleias». O propósito era o de colocar o eleitorado — reduzido em mais de $50 \%$ em relação ao do ano anterior - perante o dilema de ser «ou pelo Estado Novo ou contra o Estado Novo».

Uma vez formada a Assembleia Nacional, reeleito o Presidente da República, e composta a Câmara Corporativa, estavam de pé, juntamente com o Governo, as principais instituições que corporizariam com as suas relações o Estado Novo.

\section{Conclusão}

$O$ Estado Novo surgiu assim como novo regime, resultante da Revolução Nacional. A sua nova constituição consagra um regime republicano, embora nacionalizado, isto é, mantém o seu quadro institucional, preservando nomeadamente os seus princípios electivo e representativo, mas dando-lhe novo conteúdo e novo contexto políticos: os do nacionalismo político autoritário. Estamos assim perante uma II República, não democrática, mas antes autoritária, nacionalista e corporativista. Por outro lado, essa República nova concilia-se com a Igreja sem se deixar confessionalizar, concordatando com ela um regime de separação, mas de respeito e cooperação recíproca. O laicismo de Estado será desse modo compatibilizado com a orientação católica da acção govemativa. Por último, o autoritarismo nacionalista do Estado Novo afasta-se do modelo do partido único totalitário, acabando por ser, não uma ditadura de movimento ou de partido, mas tão só uma ditadura pessoal do chefe do governo. 